\title{
A Survey Study to Assess Soil and Leaf Major Nutrient Status in Relation to Pomegranate Yield
}

\author{
T. Anusree ${ }^{1}$, R. Suma ${ }^{2 *}$, M.S. Nagaraja ${ }^{1}$ and T. Nekha ${ }^{1}$ \\ ${ }^{1}$ Department of Soil Science \& Agricultural Chemistry, College of Horticulture, \\ Bagalkot, Karnataka, India \\ ${ }^{2}$ Zonal Agricultural Research Station, Mandya, Karnataka, India \\ *Corresponding author
}

\section{Keywords \\ Available nitrogen, Phosphorus, \\ Potassium, \\ Pomegranate fruit yield}

\section{Article Info}

Accepted:

18 August 2018

Available Online:

10 September 2018

\section{A B S T R A C T}

A survey study was conducted in one hundred and fifty pomegranate orchards situated in seven villages of Bagalkot district, Karnataka viz., Junnur, Seemikeri, Govinakoppa, Kaladagi, Sokanadagi, Chikkasamshi and Hiresamshi to assess the soil and plant major mineral nutrient concentration and its relation with pomegranate yield. The orchards cultivating Bhagwa variety of 3-7 years old and fruiting season during hasta bahar 201718 were surveyed and categorized into low (LYO) and high yielding orchards (HYO) based on their yield levels by considering the Karnataka state average productivity i.e. $11.71 \mathrm{t} \mathrm{ha}^{-1}$. Twenty three orchards having mean yield of $9.91 \mathrm{t} \mathrm{ha}^{-1}$ (Range: 7.81-11.32 $\mathrm{t}$ $\mathrm{ha}^{-1}$ ) were grouped under LYO and one hundred and twenty seven orchards were grouped under high yielding orchards with mean yield of $18.12 \mathrm{t} \mathrm{ha}^{-1}$ (Range: 12.32-25.63 $\mathrm{t} \mathrm{ha}^{-1}$ ). The average fruit yield $\left(28.9 \mathrm{~kg} \mathrm{plant}^{-1}\right)$, fruit weight $\left(389.7 \mathrm{~g}\right.$ fruit $\left.^{-1}\right)$ and number of fruits (74) were significantly higher in HYO as compared to LYO. Application of higher amount of organic manure and major nutrients through inorganic fertilizer was noticed in $\mathrm{HYO}$ as compared to LYO. However, the time of nutrient application varied greatly among the two categories. Relatively higher rate of $\mathrm{N}$ and $\mathrm{P}$ application at bahar initiation stage and very low nutrient application was noticed at rest period in LYO. The soil and leaf status of pomegranate orchards separated based on their yield levels revealed that the nitrogen content both in soil and leaf was significantly higher in LYO as compared to HYO. Hence, negative correlation was observed between pomegranate yield and $\mathrm{N}$ content both in soil (0.539) and leaf (-0.471) at flowering stage. But, the Phosphorus and Potassium content were significantly higher in HYO as compared to LYO indicating positive correlation with pomegranate yield.

\section{Introduction}

Pomegranate (Punica granatum. L), known as "Dadima" in Ayurveda is an important fruit crop in arid and semiarid region. It has high demand in internal markets as well as export potential owing to its anti-oxidant values. The popular crop, native from Iran, belongs to the family, lythraceae. In India, it is extensively grown in Maharashtra, Karnataka and Andhra Pradesh and it is an upcoming crop in Gujarat, Tamil Nadu, Uttar Pradesh, Haryana and Rajasthan. In Karnataka, pomegranate is cultivated on an area of 28.09 thousand ha 
with an annual production of 328.92 thousand MT and productivity of $11.71 \mathrm{MT} \mathrm{ha}^{-}$ ${ }^{1}$ (Ministry of Agriculture and Farmers Welfare, Government of India, 2017), in districts of Vijayapura, Koppal, Bagalkot, Belgaum, Dharwad, Chitrdurga and Bellary. Though the area under pomegranate cultivation has increased tremendously, productivity has not increased to the desired extent. One of the key reasons behind low productivity is inadequate nutrition (Marathe et al., 2016) leading to higher susceptibility to disease infestation. This calls for more studies on nutrient management in pomegranate.

During recent years, pomegranate intensive cropping system involving bahar treatment (manipulation of flowering and fruit setting involving plant hormones) calls for proper nutrient management which otherwise may deteriorate plant health and make them susceptible for several biotic and abiotic stresses. The current goals of pomegranate production are to achieve high fruit yield and quality fruit. For achieving this optimum nutrient supply and assimilation by plants are of utmost importance. Long term and continuous application of one favored nutrient may lead to its accumulation in soil resulting in the increased concentration and buildup of nutrient that may interact with other nutrients influencing either synergism or antagonism (Ahmad et al., 2011).

It is obvious that the quality of produce depends up on the inherent fertility and productivity of soil. To increase the crop yield, the efficient use of fertilizers by matching nutrient application to crop requirement is more important. Soil analysis gives an idea about actual status of nutrient availability for the assimilation by the plant while, leaf analysis diagnoses the nutritional status of plant which ascertains the nutrient requirement for a given crop. Optimum requirement is based on the assumption that there is a positive relationship between the doses of nutrient supplied, leaf nutrient and yield. This association between nutritional status and pomegranate productivity helps in affirming site specific recommendations. Hence, the present study aims at measuring the mineral nutrient concentration both in soil and plant and assessing its relation with pomegranate yield through survey study in Bagalkot district, Karnataka.

\section{Materials and Methods}

\section{Study area}

The present survey was conducted in Bagalkot that comes under Northern Dry Zone of Karnataka. In Bagalkot district, it is majorly grown in talukas of Bagalkot and Mudhol, followed by Bilagi and Hunugund and in small area at Badami and Jamkandi. One hundred and fifty pomegranate orchards were selected randomly from seven villages viz., Junnur, Seemikeri, Govinakoppa, Kaladagi, Sokanadagi, Chikkasamshi and Hiresamshi for the present survey to study the relation between soil and plant nutrient status with pomegranate productivity. The details of the location and orchards are presented in table 1.

The farmers of respective orchards were selected as contact farmers and the basic criteria used for selection of orchards were variety (Bhagwa), crop age (3-7yrs) and season (hasta bahar 2017-18).

\section{Categorization of pomegranate orchards}

The survey orchards were categorized based on their yield levels by considering the Karnataka state average productivity i.e., $11.71 \mathrm{t} \mathrm{ha}^{-1}$. The orchards with yield levels lesser than $11.71 \mathrm{t} \mathrm{ha}^{-1}$ were grouped as low yielding orchards (LYO) and with the yield levels greater than $11.71 \mathrm{t} \mathrm{ha}^{-1}$ were considered as high yielding orchards (HYO). 


\section{Collection of pomegranate yield and yield parameters}

Three healthy pomegranate plants from each orchard were selected randomly and labelled for recording the yield parameters. Weight of marketable fruit from all three labelled plants was recorded in each pickings (4-5) and cumulative weight computed to express fruit yield per plant in kilo gram.

The total number of fruits was counted from all the three labelled plants and average was computed to indicate the number of fruits per plant. Then total weight of fruits harvested from three selected plants was measured and the fruit weight was calculated using following formula and expressed in gram per fruit.

Total weight of fruits

Fruit weight $($ gram/fruit $)=-$----------------

The information on marketed pomegranate fruit yield was collected from contact farmers through personal interview. Then, by considering the actual area of the orchard, the fruit yield was computed for one hectare area and expressed in tones per hectare.

\section{Collection of soil and leaf sample}

The soil samples were collected from the vicinity of the selected plants for $0-15 \mathrm{~cm}$ depth and appropriately $45 \mathrm{~cm}$ away from the dripper position using post hole auger and composite samples were prepared using quartering technique. The index tissue identified for pomegranate plant tissue analysis i.e. eight pair of leaf from nonbearing shoot (Raghupati and Bhargava 1998b), was collected from the labelled plants where, soil samples were collected from all orchards separately, at flowering stage to study their nutrient contents.

\section{Preparation of samples}

The collected soil samples were air dried, pounded using wooden pestle and mortar, sieved $(2 \mathrm{~mm})$ and stored in air tight polyethylene bags for further analysis. Similarly plant samples were powdered using stainless steel mixer jar and preserved in air tight plastic cover for further analysis.

\section{Estimation of major nutrients in soil}

Alkaline permanganate method developed by Subbiah and Asija (1956) was used to determine available nitrogen content in soil. A known weight of soil was distilled with 0.32 per cent $\mathrm{KMnO}_{4}$ and 2.5 per cent $\mathrm{NaOH}$ using semi- automated N-distillation unit. The ammonia liberated is trapped in 2 per cent boric acid + mixed indicator was titrated against standard $\mathrm{H}_{2} \mathrm{SO}_{4}$ solution for determining available nitrogen content in soil. Available phosphorus from soil was extracted using Olsen's extractant. The blue colour was developed by ascorbic acid method and the intensity was read at $660 \mathrm{~nm}$ using spectrophotometer and calculated referring to P-standard curve in terms of $\mathrm{P}_{2} \mathrm{O}_{5} \mathrm{~kg} \mathrm{ha}^{-1}$ (Jackson, 1973). Available potassium was extracted from soil using neutral normal ammonium acetate (1:5), soil to extractant ratio and the concentration of potassium in the extract was determined using Flame photometer by calibrating with standards and calculated in terms of $\mathrm{K}_{2} \mathrm{O} \mathrm{kg} \mathrm{ha}{ }^{-1}$ (Jackson 1973).

\section{Estimation of major nutrients in plants}

Nitrogen content in leaf was determined by Kjeldhal distillation method. A known weight $(0.50 \mathrm{~g})$ of sample was digested with conc. $\mathrm{H}_{2} \mathrm{SO}_{4}$ and digestion mixture $\left(\mathrm{CuSO}_{4}: \mathrm{K}_{2} \mathrm{SO}_{4}\right.$ : Se-100:40:1). The digested samples were distilled for estimating $\mathrm{N}$-content as outlined by Piper (1966).Concentration of phosphorus 
in di-acid digested sample was estimated by phospho-vanado-molybdate complex method. Yellow colour was read using spectrophotometer at $430 \mathrm{~nm}$ and was estimated by referring to standard curve (Piper, 1966). The di-acid digest sample was fed to a calibrated flame photometer and per cent potassium was calculated by following Piper (1966) method.

\section{Statistical analysis}

The soil and leaf properties of pomegranate orchards were separated based on their yield levels falling into respective categories. Then one way ANOVA was studied to find the significance difference between the categories. Simple correlation between pomegranate yield and nutrient variables in leaf and soils were calculated using Pearson product moment correlation coefficient (r). The MS-office excel programme was used for calculating the simple correlation matrix. The perfect linear correlation was attained when $r= \pm 1$ and $r=0$ implies that $\mathrm{x}$ and $\mathrm{y}$ tend to have no linear relationship. The table $\mathrm{r}$ values 0.361 @ $\mathrm{p}<0.05$ and $0.467 @ \mathrm{p}<0.01$ were used to determine the significance of relationship between two variables (Snedecor and Cochran, 1981).

\section{Results and Discussion}

\section{Pomegranate yield and yield parameters}

The average pomegranate productivity of Karnataka state $\left(11.71 \mathrm{t} \mathrm{ha}^{-1}\right)$ was considered for categorizing the pomegranate orchards into low and high yielding. Accordingly, twenty three orchards with their yield ranging from 7.81-11.32 $\mathrm{t} \mathrm{ha}^{-1}$ and average yield of $9.91 \mathrm{t}$ $\mathrm{ha}^{-1}$ were grouped under LYO. Similarly one hundred and twenty seven orchards were grouped under HYO with their yield ranging from 12.32-25.63 $\mathrm{t} \mathrm{ha}^{-1}$ and average yield of $18.12 \mathrm{t} \mathrm{ha}^{-1}$ (Table 2).
Significant variation was found with respect to fruit yield $\left(\mathrm{t} \mathrm{ha}^{-1}\right.$ and $\left.\mathrm{kg} \mathrm{plant}^{-1}\right)$, fruit weight $\left(\mathrm{g}\right.$ fruit ${ }^{-1}$ ) and number of fruits between the two groups. Significantly higher fruit yield of $18.12 \mathrm{t} \mathrm{ha}^{-1}$ and $28.93 \mathrm{~kg} \mathrm{plant}^{-1}$ were observed in HYO as compared to $9.91 \mathrm{t} \mathrm{ha}^{-1}$ and 15.92 $\mathrm{kg} \mathrm{plant}^{-1}$ in lower yielding orchards (Table 2). Similarly significantly higher fruit weight of $389.7 \mathrm{~g}$ fruit $^{-1}$ and fruit number of 74 per plant was recorded in HYO as compared to LYO (264.3 $\mathrm{g}$ fruit $^{-1}$ and 60 respectively) (Table 2).

Number of fruits on each plant is one of the important factors that govern yield and quality of pomegranate. It is recommended to retain 60-80 fruits in fully grown up trees (NRCP, Solapur, 2014). However, depending on plant vigor and canopy, farmers regulate fruit number and this plays significant role in developing good size and quality of fruits. Fruit weight is also an important quality parameter used for grading and marketing. Pomegranate fruit weight is governed by many factors viz., number of fruits, fruit position, climatic condition and most importantly mineral nutrition (Sheikh and Rao, 2010). The mineral elements that are contributing for fruit yield are responsible for better fruit weight (Ray et al., 2014).

\section{Nutrient application rates pomegranate orchards}

The details of amount of nitrogen $(\mathrm{N})$, phosphorus $\left(\mathrm{P}_{2} \mathrm{O}_{5}\right)$ and potassium $\left(\mathrm{K}_{2} \mathrm{O}\right)$ and organic matter applied through inorganic and organic fertilizers is presented in table 3 . Wide variation was recorded in terms $\mathrm{N}$ application rate to pomegranate plants at bahar initiation stage recording a range of $0-48 \mathrm{~g}^{-1 a n t^{-1}}$ in HYO and 70.18-79.61 g plant ${ }^{-1}$ in LYO. But, significantly higher total $\mathrm{N}$ application was observed in HYO (412.7 $\mathrm{g}^{\text {plant }}{ }^{-1}$ ) as compared to LYO (387.4 $\mathrm{g}$ plant $\left.^{-1}\right)$. The total amount of $\mathrm{N}$ application through inorganic fertilizer was below the recommended rate for 
different ages (3-7 years) of pomegranate plants by various farm institutes (400-625 g plant $^{-1}$; NRCP, Solapur, UHS Bagalkot and UAS Dharward). The contact farmers opined that they discourage $\mathrm{N}$ application during bahar initiation stage to suppress foliage or vegetation growth and encourage flowering. They indicated that application of organic matter is good during the Bahar initiation than inorganic $\mathrm{N}$ application. Phosphorus application recorded significantly higher total amount of $200.2 \mathrm{~g} \mathrm{plant}^{-1}$ in HYO as compared to $182.0 \mathrm{~g} \mathrm{plant}^{-1}$ in LYO (Table 3 ). The cumulative information collected from the respondent farmers indicated the use of high $\mathrm{P}$ containing inorganic fertilizers viz., DAP for soil application and mono ammonium phosphate (12:61:0), mono potassium phosphate $(0: 52: 34)$ and phosphoric acid through fertigation. However, the total amount of $\mathrm{P}$ application rate was nearer to recommended rate (200-250 $\left.\mathrm{g}_{\text {plant }}{ }^{-1}\right)$ by different farm institutes in HYO while it was relatively low in LYO.

The application rate of potassium $\left(\mathrm{K}_{2} \mathrm{O}\right)$ did not vary significantly among low and high yielding pomegranate orchards (Table 3). However, marginally higher amount of $\mathrm{K}_{2} \mathrm{O}$ (226.3 $\mathrm{g} \mathrm{plant}^{-1}$ ) application was noticed in HYO as compared to LYO (205.1 $\left.\mathrm{g} \mathrm{plant}^{-1}\right)$. The rate of $\mathrm{K}_{2} \mathrm{O}$ application was found to be on par with recommendation (125-250 $\mathrm{g}$ plant $^{-1}$ ) by various farm institutes. The rate of $\mathrm{K}_{2} \mathrm{O}$ application was found to be on par with recommendation $\left(125-250 \mathrm{~g}\right.$ plant $\left.^{-1}\right)$ by various farm institutes. Organic matter application recorded was higher $(30.01 \mathrm{~kg}$ plant $^{-1}$ ) in HYO than LYO (13.30 kg plant $\left.{ }^{-1}\right)$.

\section{Major nutrient status $\left(\mathrm{N}, \mathrm{P}_{2} \mathrm{O}_{5}\right.$ and $\left.\mathrm{K}_{2} \mathrm{O}\right)$ in soils of pomegranate orchards}

Significant variation in major nutrient status was observed with available $\mathrm{N}, \mathrm{P}_{2} \mathrm{O}_{5}$ and $\mathrm{K}_{2} \mathrm{O}$ among various categories of orchards. HYO recorded significantly higher mean available $\mathrm{P}_{2} \mathrm{O}_{5}$ content of $48.13 \mathrm{~kg} \mathrm{ha}^{-1}$ and available $\mathrm{K}_{2} \mathrm{O}$ content of $219.7 \mathrm{~kg} \mathrm{ha}^{-1}$ as compared to 41.65 and $192.8 \mathrm{~kg} \mathrm{ha}^{-1}$ available $\mathrm{P}_{2} \mathrm{O}_{5}$ and $\mathrm{K}_{2} \mathrm{O}$ respectively in LYO (Table 4). Relatively high alkaline soil $\mathrm{pH}$ in LYO might have precipitated applied $\mathrm{P}$ into insoluble calcium phosphates rendering decreased availability (Wastermann and Leytem, 2003, Abdou, 2006 and Bertnand et al., 2006). Application of higher organic matter content to soil at bahar initiation time might have helped to increase soil $\mathrm{P}$ by decreasing soil $\mathrm{pH}$ through organic acid production (Ritchi and Dolling, 1985) there by process of solubilizing the fixed soil $\mathrm{P}$ (Ray et al., 2014), besides release of $\mathrm{P}$ during decomposition (Radwaski and Wickens, 1981). Lower $\mathrm{K}_{2} \mathrm{O}$ content in LYO may be attributed to lower rate of $\mathrm{K}_{2} \mathrm{O}$ and organic matter application at bahar initiation stage in LYO as compared to HYO. Whereas available $\mathrm{N}$ was significantly higher in LYO with a mean of $451.8 \mathrm{~kg} \mathrm{ha}^{-1}$ as compared to HYO (406.0 kg ha-1). Relatively higher rate of application of inorganic fertilizer at bahar initiation might have contributed to higher availability of $\mathrm{N}$ in these soils (Saraf et al., 2001, Sheikh and Rao, 2010, Ghosh et al., 2012, Ahmed et al., 2014, Kashyap et al., 2012).

\section{Pomegranate major leaf nutrient concentration ( $N, P$ and $K$ ) in low and high yielding orchards}

Nitrogen content in pomegranate leaves varied significantly among the two groups. Higher nitrogen content in leaves was noted in LYO orchards ranging from 1.51 to 1.96 per cent, with average $\mathrm{N}$ content of 1.73 per cent, as compared to 1.4 per cent in HYO (Table 5). This may be attributed to $\mathrm{N}$ application rate and its higher availability in soils that might have resulted in higher accumulation in succulent leaves at flowering stage (Lominadze et al., 2016, Kolekar et al., 2018). 
Table.1 Details of pomegranate orchards selected for the study

\begin{tabular}{|c|l|c|c|c|c|}
\hline SI. No. & Village Name & Longitude & Latitude & No of orchards & Age of orchards \\
\hline $\mathbf{1}$ & Junnur & $16.232 \mathrm{~s} 10^{0} \mathrm{~N}$ & $075.44176^{0} \mathrm{E}$ & 12 & $3.5-6.5$ \\
\hline $\mathbf{2}$ & Kaladagi & $16.19493^{0} \mathrm{~N}$ & $075.50330^{0} \mathrm{E}$ & 45 & $3-7$ \\
\hline $\mathbf{3}$ & Sokanadagi & $16.22876^{0} \mathrm{~N}$ & $075.57455^{0} \mathrm{E}$ & 41 & $3.5-6$ \\
\hline $\mathbf{4}$ & Chikkasamshi & $16.23474^{0} \mathrm{~N}$ & $075.53139^{0} \mathrm{E}$ & 23 & $3-5.5$ \\
\hline $\mathbf{5}$ & Govinakoppa & $16.20231^{0} \mathrm{~N}$ & $075.52857^{0} \mathrm{E}$ & 14 & $3-6$ \\
\hline $\mathbf{6}$ & Seemikeri & $16.16227^{0} \mathrm{~N}$ & $075.57851^{0} \mathrm{E}$ & 10 & $4-7$ \\
\hline $\mathbf{7}$ & Hiresamshi & $16.22532^{0} \mathrm{~N}$ & $075.52793^{0} \mathrm{E}$ & 5 & $3-4.5$ \\
\hline
\end{tabular}

Table.2 Yield and yield parameters of low and high yielding pomegranate orchards

\begin{tabular}{|l|l|l|l|l|}
\hline \multirow{2}{*}{ Yield Parameters } & Low yielding $(\mathbf{n}=\mathbf{2 3})$ & \multicolumn{2}{l|}{ High Yielding $(\mathbf{n = 1 2 7})$} \\
\hline & Range & Average & Range & Average \\
\hline Fruit yield $\left(\right.$ tonnes ha $\left.^{-1}\right)$ & $7.81-11.32$ & $9.91 \pm 0.8^{\mathrm{b}}$ & $12.32-25.63$ & $18.12 \pm 3.3^{\mathrm{a}}$ \\
\hline Fruit yield $\left(\mathrm{kg}^{-1}\right.$ plant- $\left.{ }^{-1}\right)$ & $12.43-18.0$ & $15.92 \pm 1.30^{\mathrm{b}}$ & $19.63-40.91$ & $28.93 \pm 5.2^{\mathrm{a}}$ \\
\hline Fruit weight (gram fruit $\left.{ }^{-1}\right)$ & $198.0-306.4$ & $264.3 \pm 27.3^{\mathrm{b}}$ & $245.8-587.5$ & $389.7 \pm 66.3^{\mathrm{a}}$ \\
\hline Number of fruits per plant & $53-72$ & $60 \pm 3.6^{\mathrm{b}}$ & $61-86$ & $74 \pm 6.0^{\mathrm{a}}$ \\
\hline
\end{tabular}

${ }^{\text {ns }}$ non-significant, means of same parameter with different letters are statistically significant at $\mathrm{p}<0.05$ among low and high yielding orchards

Table.3 Nutrient application rates in low and high yielding orchards

\begin{tabular}{|c|c|c|c|c|c|c|}
\hline \multirow{2}{*}{$\begin{array}{l}\text { Nutrients } \\
\left.\text { (g plant }^{-1}\right)\end{array}$} & \multirow[t]{2}{*}{ Category } & \multirow{2}{*}{$\begin{array}{c}\text { Bahar } \\
\text { initiation } \\
\text { Range }\end{array}$} & \multirow{2}{*}{$\begin{array}{l}\text { Active } \\
\text { growth } \\
\text { Range }\end{array}$} & \multirow{2}{*}{$\begin{array}{l}\text { Rest } \\
\text { period } \\
\text { Range }\end{array}$} & \multicolumn{2}{|c|}{ Total } \\
\hline & & & & & Range & Average \\
\hline \multirow[t]{2}{*}{ Nitrogen } & $\begin{array}{l}\text { Low } \\
\text { yielding }\end{array}$ & $70.18-79.61$ & $\begin{array}{l}221.3- \\
321.3\end{array}$ & $0-86.3$ & $318.1-420.5$ & $387.4 \pm 19.9^{b}$ \\
\hline & $\begin{array}{l}\text { High } \\
\text { yielding }\end{array}$ & $0-48.8$ & $\begin{array}{l}238.4- \\
332.6\end{array}$ & $0-94.3$ & $358.6-456.8$ & $412.7 \pm 33.5^{\mathrm{a}}$ \\
\hline \multirow[t]{2}{*}{$\begin{array}{l}\text { Phosphorus } \\
\left(\mathrm{P}_{2} \mathrm{O}_{5}\right)\end{array}$} & $\begin{array}{l}\text { Low } \\
\text { yielding }\end{array}$ & $56.6-92.6$ & $78.9-124.3$ & $0-58.6$ & $171.0-215.1$ & $182.0 \pm 9.9^{\mathrm{b}}$ \\
\hline & $\begin{array}{l}\text { High } \\
\text { yielding }\end{array}$ & $0-112.6$ & $58.6-110.3$ & $60.1-94.3$ & $173.1-269.4$ & $200.2 \pm 13.2^{\mathrm{a}}$ \\
\hline \multirow[t]{2}{*}{$\begin{array}{l}\text { Potassium } \\
\left(\mathbf{K}_{2} \mathbf{O}\right)\end{array}$} & $\begin{array}{l}\text { Low } \\
\text { yielding }\end{array}$ & $42.6-59.8$ & $\begin{array}{l}132.2- \\
158.4\end{array}$ & $0-62.4$ & $178.2-224.1$ & $205.1 \pm 12.1^{\mathrm{ns}}$ \\
\hline & $\begin{array}{c}\text { High } \\
\text { yielding }\end{array}$ & $51.3-102.3$ & 76.9-138.6 & $30.1-53.2$ & $152.7-299.9$ & $226.3 \pm 50.2^{\mathrm{ns}}$ \\
\hline \multirow[t]{2}{*}{$\begin{array}{l}\text { Organic } \\
\text { matter }\end{array}$} & $\begin{array}{c}\text { Low } \\
\text { yielding }\end{array}$ & & & & $0-28$ & $13.30 \pm 10.16^{b}$ \\
\hline & $\begin{array}{l}\text { High } \\
\text { yielding }\end{array}$ & & & & $12-46$ & $30.01 \pm 7.93^{\mathrm{a}}$ \\
\hline
\end{tabular}


Table.4 Available nutrient content in soils of low and high yielding pomegranate orchards

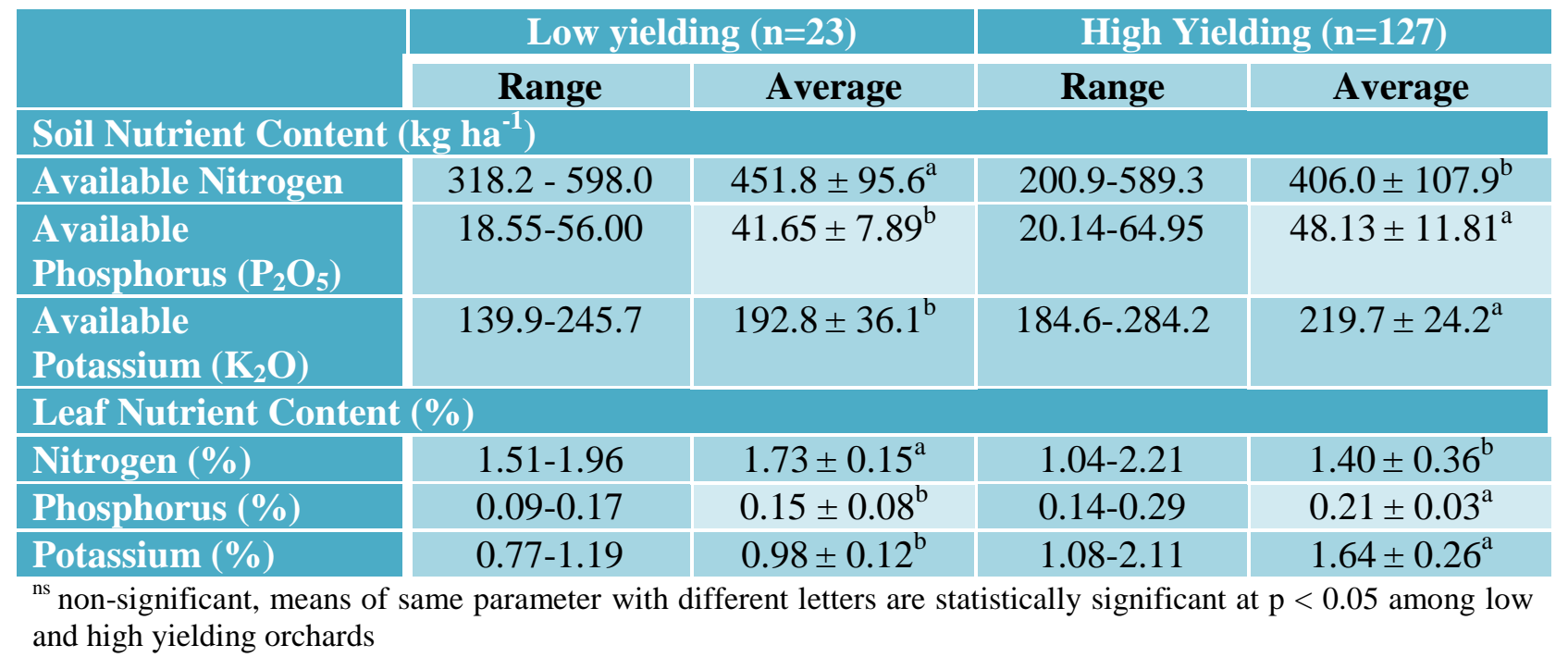

Table.5 Correlation index (r) among major soil nutrients and major leaf nutrient content at flowering stage

\begin{tabular}{|l|c|l|l|l|l|l|}
\hline & Yield & Soil N & Soil P & Soil K & Plant N & Plant P \\
\hline Soil N & $-0.539^{*}$ & & & & & \\
\hline Soil P & $0.281^{*}$ & $-0.30^{*}$ & & & & \\
\hline Soil K & $0.623^{* *}$ & $-0.42^{*}$ & $0.30^{*}$ & & & \\
\hline Plant N & $-0.471^{*}$ & $0.31^{*}$ & 0.00 & $-0.26^{*}$ & & \\
\hline Plant P & $0.546^{*}$ & $-0.31^{*}$ & $0.20^{*}$ & $0.31^{*}$ & $-0.35^{*}$ & \\
\hline Plant K & $0.613^{* *}$ & $-0.31^{*}$ & 0.13 & $0.34^{*}$ & $-0.30^{*}$ & $0.41^{*}$ \\
\hline
\end{tabular}

Soil N, P and $\mathrm{K}$ in $\left(\mathrm{kg} \mathrm{ha}^{-1}\right)$, Plant N, P and $\mathrm{K}$ in (\%) $* \mathrm{p}<0.05 * * \mathrm{p}<0.01$

Significantly higher $\mathrm{P}$ mean concentration of 0.21 per cent was recorded in $\mathrm{HYO}$ with a range of $0.14-0.29 \%$ as compared to LYO $(0.15 \%)$ (Table 5). Higher alkaline soil $\mathrm{pH}$ and lower organic matter application (Yu et al., 2013, Kumar et al., 2009, Ahmed et al., 2014, Kashyap et al., 2012) might be the reason for low $\mathrm{P}$ accumulation in LYO.

Significant variation was recorded in terms of $\mathrm{K}$ content in pomegranate leaves in high and LYO. Higher K concentration of 1.64 per cent was noticed in HYO as compared to low yielding $(0.98 \%)$ (Table 5). This may be attributed to lower rate of inorganic $\mathrm{K}$ fertilizers and organic matter application during bahar initiation stage. The higher organic matter and inorganic fertilizer application resulted in higher K availability in soil (Meek et al., 1982, Sheikh and Rao, 2010, Ghosh et al., 2012, Ahmed et al., 2014, Kashyap et al., 2012) that might enhanced its accumulation in leaves.

\section{Correlations among soil and leaf nutrient contents with pomegranate yield}

The correlation analysis among major soil nutrient parameters at flowering stage is presented in Table 5. At flowering stage, significant positive correlation was found between pomegranate yield and $\mathrm{P}(0.546)$. Phosphorus application through inorganic 
fertilizer and organic matter has resulted in higher availability in soil resulting in its optimum accumulation in pomegranate leaf in HYO (Gimenez et al., 2000, Ahmed et al., 2014 and Kashyap et al., 2012) as compared to LYO. Phosphorus is highly essential for active root growth and known to stimulate uptake of other nutrients (Marathe et al., 2016) thus showing positive relation with pomegranate yield. Pomegranate yield also showed a significant positive correlation with K (0.613). Many researches opined that potassium plays vital role in pomegranate yield and fruit quality (Sheikh and Rao, 2010, Kumar et al., 2009, Ahmed et al., 2014, Kashyap et al., 2012).

Amongst the primary nutrients, $\mathrm{N}$ showed negative relationship with yield (-0.471). LYO recorded relatively higher amount of $\mathrm{N}$ application through in organic fertilizer that resulted in higher availability in soil further, higher $\mathrm{N}$ accumulation in leaves. All these might have influenced on flowering pattern and fruit set recording lower number of fruits per plant in these orchards. Many researchers have opined that abundant nutrient supply may reduce flowering (Corbesier, et al., 2002. Bernier et al., 1981 and Rideout et al., 1992) and flowering pattern in pomegranate.

Hermaphrodite flowers are considered as perfect flowers and have positive correlation to fruit bearing (Babu, 2010, Bernier et al., 1981, Rideout et al., 1992) may be affected when $\mathrm{N}$ content is high in the plant that promote more of vegetative growth than flowering. Amongst the primary nutrients, soil $\mathrm{N}, \mathrm{P}$ and $\mathrm{K}$ are positively correlated with plant $\mathrm{N}, \mathrm{P}$ and $\mathrm{K}(\mathrm{r}=0.31,0.2$ and 0.34 respectively) (Table 5). Higher availability of nutrients in soil might have resulted in its higher accumulation in the succulent leaves at flowering (Lominadze et al., 2016, Kolekar et al., 2018).

The results of the present study has revealed optimum application rate of major nutrients especially nitrogen is essential for obtaining higher fruit number, fruit weight and fruit yield. Organic matter application is crucial in maintaining higher availability of major nutrients in soil. Rate and time of inorganic nutrient application both during rest period and active fruiting stage plays a crucial role in pomegranate productivity.

\section{References}

Abdou, A. S. (2006). Effect of applied elemental sulphur and sulphur-oxidizing bacteria (Paracoccus versutus) into calcareous sandy soils on the availability of native and applied phosphorus and some micronutrients. In: $18^{\text {th }}$ World Congress of Soil Science, Philadelphia, Pennsylvania, USA.

Ahmad, M. M. (2011). Effect of organic and inorganic fertilizers on soil health and productivity of pomegranate, Ph.D. Thesis, University of Horticulture and Forestry, Nauni (India).

Ahmed, F. F., Mohamed, M. M., Abou ElKhashab, A. M. A. and Aeed, S. H. A. (2014). Controlling the fruit splitting and improving productivity of manfalouty pomegranate trees by using salicylic acid and some nutrients. World Rural Observ. 6 (1): 87-93.

Anonymous. (2014). National Research Centre on Pomegranate, Sholapur, 26-27.

Anonymous. (2017). Horticultural glance at 2017. Ministry of Agriculture and Farmers Welfare, Government of India, 355-388.

Bernier, G., Kinet, J. M. and Sachs, R. M. (1981). The Physiology of Flowering, 1: CRC Press, Boca Raton.

Bertrand. I., McLaughlin, M. J., Holloway, R. E., Armstrong, R. D. and McBeath, T. (2006). Nutr. Cycl. in Agroeco., 74 (1): 27-40.

Corbesier, L., Bernier, G. and Perilleux, C. (2002). C: N ratio increases in the phloem sap during floral transition of the long-day plants. Sinapis alba and Arabidopsis thaliana. Plant cell Physiol. 43 (6): 684688.

Ghosh, S.N., Bera, B., Roy, S. and Kundu, A. (2012). Integrated nutrient management in pomegranate grown in laterite soil. Indian J. Hortic. 69 (3): 333-337. 
Gimenez, M., Martinez, M., Oltra, M. A., Martinez, J. J. and Ferrandez, M. (2000). Pomegraante (Punica granatum L.) leaf analysis: correlation with harvest. CIHEAM-options Mediterraneennes, 179185.

Glozer, K. and Ferguson, L. (2008). Pomegranate Production in Afghanistan. College of Agricultural and Environmental Science, 12-28.

Kashyap, P., Pramanick, K. K., Meena, K. K. and Meena, V. (2012). Effect of $\mathrm{N}$ and $\mathrm{K}$ application on yield and quality of pomegranate cv. Ganesh under rainfed conditions. Indian J. Hortic. 69 (3): 322327.

Kolekar, P.B. and Bhagyaresha, G. (2018). Studies on macro and micro nutrients status in leaf tissue of pomegranate (Punica granatum) Orchads of Latur District. International Journal of Current Microbiology and Applied Sciences, 6: 112119.

Kumar, R., Singh, J. and Verma, I. M. (2009). Influence of soil nutrient on yield and qualitative attributes of pomegranate (Punica granatum L.) cv Ganesh. Progressive Horticulture, 41 (1): 36-39.

Lominadze, S. and Nakashide, N. (2016). The influence of nitrogen fertilizers on nitrate accumulation in leaves of orange Washington Navel. Annals of agrarian science, 14(3): 233-236.

Marathe, R. A., Murkute, A. A. and Babu, D. K. (2016). Mineral Nutrient Deficiencies and Nutrient Interactions in Pomegranate. National Academy Science Letters, 39(6): 407-410.

Meek, B. Graham, L. and Donovan, T. (1982). Long-term Effects of Manure on Soil Nitrogen, Phosphorus, Potassium, Sodium, Organic Matter, and Water Infiltration Rate. Soil Science Society of America., 46(5): 1014-1019.
Radwanski, S. A. and Wickens, G. E. (1981). Vegetative fallows and potential value of the neem tree in the Tropics. Economic Botany, 33: 398-414.

Ray, S. K., Takawale, P. V., Chatterjee, R. and Hnamte, V. (2014). Yield and quality of pomegranate as influenced by organic and inorganic nutrients. The Bioscan, 9 (2): 617-620.

Rideout, J. W., Raper, C. D. and Miner, G, S. (1992). Changes in ratio of soluble sugars and free amino nitrogen in the apical meristem during floral transition of tobacco. International Journal of Plant Sciences, 153: 78- 88.

Ritchi, G. S. P. and Dolling, P. J. (1985). The role of organic matter in soil acidification. Australian Journal of Soil Research, 23(4): $569-576$.

Saraf, R. K., Samaiya, R. K. and Shukhla, K. C. (2001). Effect of different sources of nutrients on growth of pomegranate (Punica granatum L.). Proceedings of National Conference on "Biodiversity and sustainable utilization of biological resources", 203-208.

Sheikh, M. K. and Rao, M. M. (2010). Effect of split application of $\mathrm{N}$ and $\mathrm{K}$ on growth and yield of pomegranate. Karnataka Journal Agricultural Sciences, 18 (3): 854-856.

Snedecor, G.W., Cochran, W.G. (1981). Statistical methods, seventh ed. Iowa State University Press, Iowa, USA.

Westermann, D. T. and Leytem, A. B. (2003). Soil factors affecting $P$ availabilities in western soils. USDA-ARS. WNM Salt Lake.

Yu, W., Ding, X., Xue, S., Li, S., Liao, X. and Wang, R. (2013). Effects of organic-matter application on phosphorus adsorption of three soil parent materials. Journal of Soil Science and Plant nutrition., 13: 4.

\section{How to cite this article:}

Anusree, T., R. Suma, M.S. Nagaraja and Nekha, T. 2018. A Survey Study to Assess Soil and Leaf Major Nutrient Status in Relation to Pomegranate Yield. Int.J.Curr.Microbiol.App.Sci. 7(09): 25972605. doi: https://doi.org/10.20546/ijcmas.2018.709.323 